\title{
Penerapan Ulangan Harian Matematika Menggunakan PHT Berbasis Android di SMP Muhammadiyah 7 Surakarta
}

\author{
Nidaul Hasanah ${ }^{1)}$, Linda Asmawati ${ }^{2)}$, Aprilia Saputri Riski Pratiwi ${ }^{3)}$, \\ Nur Alifa Aulia Putri ${ }^{4)}$, Indah Dwi Utami ${ }^{5)}$, Hepy Adityarini6) \\ 1)2)3)4)5)6) Universitas Muhammadiyah Surakarta \\ 1)Nidaul.hasanah2000@gmail.com, ${ }^{2}$ Lindaasmawati490@gmail.com, \\ ${ }^{3)}$ saputririski7874@gmail.com, ${ }^{4)}$ auliaputri.bms@gmail.com, \\ 5)indahdwiutami354@gmail.com, ${ }^{6}$ hepy.audityarini@ums.ac.id \\ doi: 10.23917/blbs.v2i1.11606
}

\begin{abstract}
Abstrak. Tuntutan global menuntut dunia pendidikan di Indonesia agar menyesuaikan perkembangan teknologi dalam peningkatan mutu pendidikan. Penelitian dilakukan untuk mendeskripsikan penerapan ulangan harian matematika menggunakan PHT (Penilaian Harian Terstruktur) berbasis android. Dalam penelitian ini metode yang digunakan yaitu deskriptif kualitatif dan deskriptif kuantitatif dengan jumlah sampel 23 siswa. Teknik pengambilan data yang digunakan adalah dengan observasi lingkungan sekolah, wawancara narasumber dengan guru dan teknisi, serta angket responden siswa terhadap PHT berbasis android. Simpulan dari penelitian ini adalah penerapan PHT berbasis android dari perspektif guru dan teknisi sudah cukup baik namun, dari prespektif siswa masih kurang diminati.
\end{abstract}

Kata Kunci: android, global, teknologi, ulangan harian, PHT

\section{PENDAHULUAN}

Program Pengenalan Lapangan Persekolahan I (PLP I) di SMP Muhammadiyah 7 Surakarta terdiri dari beberapa aktivitas penting antara lain melakukan observasi struktur organisasi dan tata kerja di sekolah, kultur sekolah, dan pelibatan aktivitas pendidikan di sekolah. Seluruh informasi yang diperoleh dalam melakukan beberapa aktivitas di sekolah selanjutnya disusun dalam bentuk Program Kreativitas Mahasiswa Artikel Ilmiah (PKM-AI). Tujuan dari PLP I adalah mampu mendeskripsikan hasil observasi di sekolah dan mampu membentuk 4 kompetensi guru profesional, yaitu: kompetensi kepribadian, kompetensi sosial, kompetensi pedagogik, dan kompetensi professional. Manfaat dari PLP I adalah mampu mengembangkan ilmu pengetahuan secara teoritis dan mampu mengatasi, memecahkan, daan mencegah masalah yang ada pada objek yang diteliti,

Matematika sebagai salah satu mata pelajaran di sekolah yang dinilai sangat memegang peranan penting dalam berbagai aspek kehidupan termasuk meningkatkan kemampuan siswa untuk berpikir secara kritis, sistematis, logis, kreatif, dan bekerja sama secara efektif (Titis dkk, 2019). Perkembangan teknologi dan informasi saat ini sudah menyentuh semua aspek kehidupan masyarakat Indonesia, mulai dari komunikasi, bisnis, kehidupan 
sosial, sampai pendidikan (Stephanie dkk, 2013). Dalam berbagai institusi pendidikan, khususnya untuk SMP banyak yang mampu menguasai dan mengaplikasikan android dengan baik. Di zaman revolusi industri 4.0, android merupakan salah satu produk teknologi yang cukup umum ditemukan di masyarakat. Tuntutan global menuntut dunia pendidikan untuk selalu menyesuaikan perkembangan teknologi, informasi, dan komunikasi terhadap usaha dalam peningkatan mutu pendidikan. Teknologi dalam dunia pendidikan digunakan untuk mendukung berbagai kegiatan administratif dan belajar mengajar.

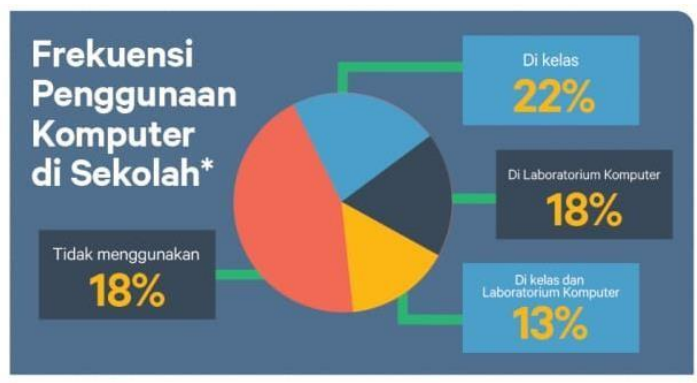

Gambar 1. Frekuensi Penggunaan Komputer di Sekolah (Sumber: blog.ruangguru.com)

Berdasarkan gambar yang dilansir dari blog resmi ruangguru mengatakan bahwa pemanfaatan teknologi dalam pendidikan di Indonesia seperti penggunaan komputer di sekolah belum cukup signifikan dan dapat terjadi karena salah satunya infrastruktur yang kurang memadai seperti akses internet (blog.ruangguru.com). Penggunaan android untuk mendukung proses belajar mengajar dan ulangan harian bahkan ujian semester belum maksimal. Selain itu, penggunaan komputer dalam fungsi yang sama ini juga masih sangat kurang di kalangan SMP. Android hanya digunakan oleh guru untuk membuat soal ulangan sedangkan pelaksanaan, pemeriksaan, dan penilaian dilakukan secara manual.

Adapun beberapa penelitian yang telah dilakukan terkait dengan penerapan teknologi dalam pembelajaran matematika, pengembangan Media Pembelajaran Matematika dengan Macromedia Flash (Rubhan Masykur dkk, 2017) Hasil dari penelitian ini adalah aplikasi Macromedia Flash masuk ke dalam kategori layak untuk digunakan sebagai alat pengembangan media pembelajaran matematika dan aplikasi Macromedia Flash masuk ke dalam kategori sangat menarik dalam segi tampilan. Selain itu, aplikasi Ulangan Harian untuk Siswa SMA Berbasis Client Server (Stephanie dkk, 2013) Hasil dari penelitian ini adalah Aplikasi ini 
mampu mempermudah dalam pembuatan soal dan aplikasi ini dapat mempermudah proses ulangan harian serta dapat mengurangi tingkat kecurangan. Serta pengembangan Aplikasi Ujian Akhir Semester Berbasis Komputer di SMK Darul Arqam Makassar (Hamsu dkk, 2017) Hasil penelitian menghasilkan produk berupa aplikasi ujian valid, efektif, dan praktis digunakan sebagai aplikasi ujian akhir semester berbasis komputer di SMK Darul Arqam Makassar.

Pada sistem manual, ulangan harian biasanya berisi soal yang berkaitan tentang suatu bab atau beberapa bab. Maka, setiap kali akan mengadakan ulangan harian mengenai bab tersebut, guru harus menyusun ulang soal yang dikehendaki dan kemudian mencetak ulang soal tersebut. Kemudian ada proses penilaian yang memakan waktu lama. Selain itu, saat ulangan harian manual dilaksanakan perlu pengawasan yang ketat agar menghindari kecurangan dalam mengerjakan soal tertulis. Flesibilitas pengacakan soal pun terbatas sehingga mempermudah kerja sama antara siswa.

Semua permasalahan tersebut sangat tidak efesien dan tidak efektif. Hal ini dapat terjadi juga karena beberapa faktor, yaitu kurangnya kepedulian terhadap lingkungan misalnya dalam penghematan penggunaan kertas dan kurangnya sosialisasi dari pemerintahan kepada beberapa instansi mengenai pentingnya mengikuti peradaban zaman modern.

Berdasarkan uraian tersebut, peneliti tertarik untuk melakukan penelitian tentang penerapan PHT (Penilaian Harian Terstruktur) berbasis android dalam pembelajaran matematika di SMP Muhammadiyah 7 Surakarta.

Rumusan masalah yang akan dipecahkan melalui penelitian ini pada dasarnya tidak terlepas dari ruang lingkup permasalahan di atas yaitu (a) Bagaimanakah penerapan PHT berbasis android pada ulangan harian matematika menggunakan PHT berbasis android di SMP Muhammadiyah 7 Surakarta?, (b) Bagaimanakah perspektif guru terhadap ulangan harian matematika menggunakan PHT berbasis android di SMP Muhammadiyah 7 surakarta?, (c) Bagaimanakah perspektif siswa terhadap ulangan harian matematika menggunakan PHT berbasis android di SMP Muhammadiyah 7 surakarta?

Adapun Tujuan yang hendak dicapai dari penelitian ini adalah (a) Mendeskripsikan penerapan PHT berbasis android pada ulangan harian matematika di SMP Muhammadiyah 7 Surakarta, (b) Mendeskripsikan perspektif guru terhadap PHT berbasis android pada ulangan harian matematika di SMP Muhammadiyah 7 surakarta, (c) Mendeskripsikan perspektif siswa terhadap PHT berbasis android pada ulangan harian matematika di SMP Muhammadiyah 7 surakarta. 


\section{METODE PENELITIAN}

Metode yang dilakukan oleh peneliti menggunakan model gabungan dua metode yaitu deskriptif kualitatif dan deskriptif kuantitatif. Penelitian ini dilaksanakan di SMP Muhammadiyah 7 Surakarta selama 10 hari mulai tanggal 27-31 Januari 2020 dan 37 Februari 2020. Penelitian dilaksanakan bersamaan dengan kegiatan PLP I mulai pukul 07.00-15.30 WIB. Sasaran dalam penelitian Penerapan Ulangan Harian Matematika Menggunakan PHT Berbasis Android adalah guru, teknisi atau tata usaha, dan siswa kelas VIII A Tahun Ajaran 2019/2020.

Teknik pengambilan data berdasarkan hasil observasi sekolah, wawancara narasumber, dan angket responden. Observasi sekolah dilakukan untuk mengetahui kondisi lingkungan sekolah terhadap pengaruh pelaksanaan salah satu program sekolah yaitu PHT berbasis android. Wawancara narasumber dilakukan dengan guru dan teknisi atau tata usaha. Wawancara ini dilakukan untuk mengetahui informasi sistematika dan perspektif pelaksanaan PHT berbasis android. Angket responden dilakukan dengan siswa sebagai uji coba lapangan terdiri dari 22 siswa pada kelas VIII A program Global untuk mengetahui informasi mengenai pandangan atau perspektif siswa terhadap PHT berbasis android. Kelas VIII A Program Global dipilih karena siswa pada kelas itu lebih aktif, kemampuan siswanya heterogen, dan fasilitas kelas yang sangat memadai sehingga sering disebut sebagai kelas VIII unggulan di SMP Muhammdiyah 7 Surakarta.

\section{HASIL PENELITIAN DAN PEMBAHASAN}

\section{Penerapan PHT Berbasis Android}

Salah satu program SMP Muhammadiyah 7 Surakarta yaitu PHT berbasis android yang didukung oleh aplikasi Zambro dan website Zya Cbt. Program sekolah ini telah berjalan 2,5 tahun. Contoh PHT adalah ulangan harian untuk siswa dari guru secara pribadi atau kelas. Sekolah juga mengadakan tes uji bersama secara serentak atau sebagai persiapan sebelum PTS (Penilaian Tengah Semester) dan PAS (Penilaian Akhir Semester). PHT diadakan 1,5 dari jangka tengah semester dan dalam setahun. PHT diadakan sebanyak 4 kali yang memiliki akun resmi milik sekolah dan diatur langsung oleh guru tata usaha sekolah. Hal ini dibuktikan dengan sebuah kutipan percakapan sebagai berikut: 
Wakasek kurikulum: PHT merupakan penilaian harian terstruktur.Jadi kita memberikan penilaian kepada anak melalui guru dan uji bersama. Setahun kita melaksanakan 4 kali dan sudah menjadi program sekolah selama 2,5 tahun.

Berikut adalah screenshoot tampilan awal website Zya Cbt dan aplikasi Zambro.

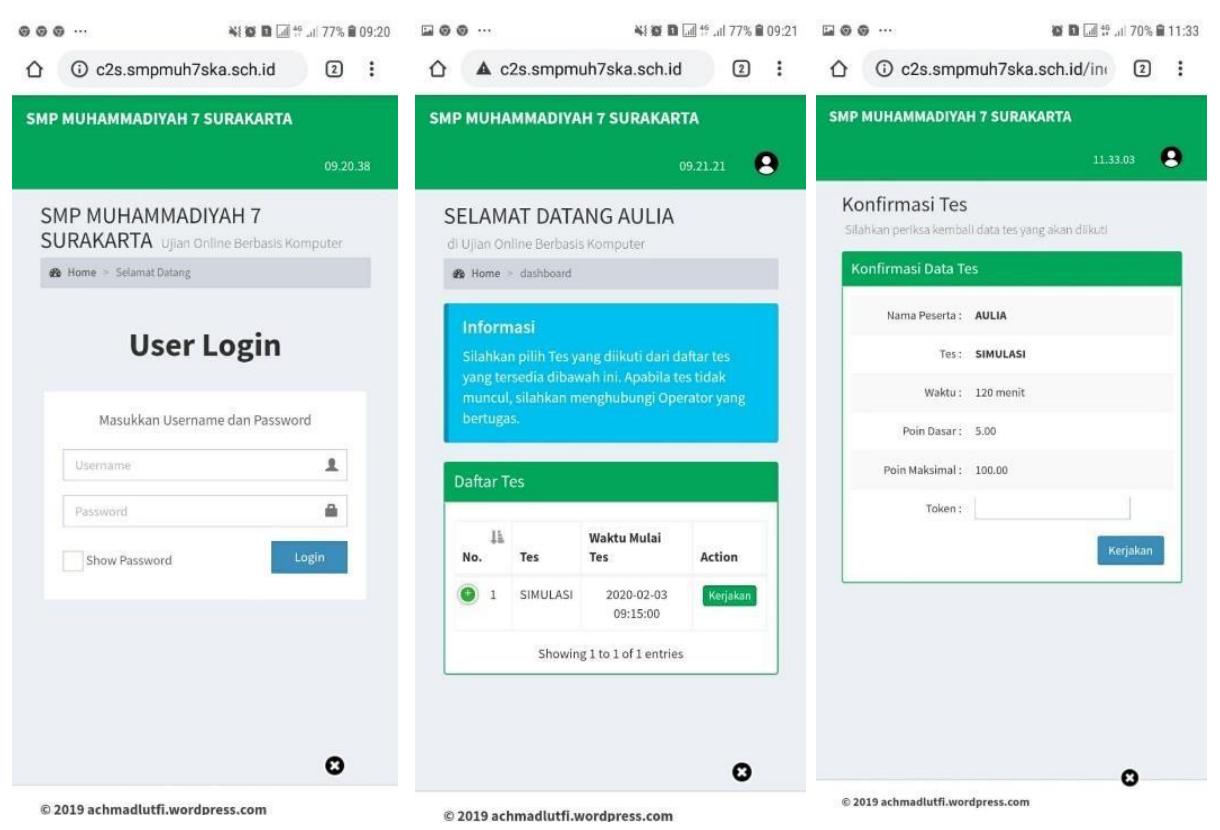

Gambar 2. Tampilan Awal Website Zya Cbt

(Sumber: Website Zys Cbt)
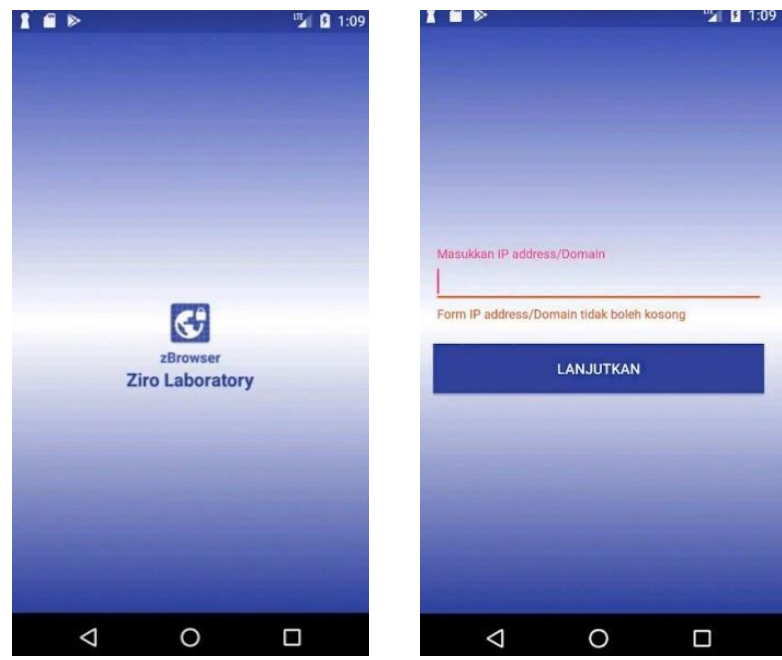

Gambar 3. Tampilan Awal Aplikasi Zambro

(Sumber: Aplikasi Zambro)

Sistem PHT di SMP Muhammadiyah 7 Surakarta menggunakan 
sistem online yang berbasis android maupun PC. Aplikasi ini bisa dilaksanakan menggunakan handphone maupun komputer. Pelaksanaan PHT diatur oleh Wakasek Kurikulum Sekolah seperti jadwal ujian, kegiatan mata pelajaran, dan lain-lainnya yang berkaitan dengan kurikulum pembelajaran. Untuk teknisi yang merupakan salah satu guru tata usaha mendapatkan tugas memasukkan data siswa daan pengaturan tes. Untuk soal ujian merupakan tanggung jawab dari guru masing-masing. Hal ini dapat dibuktikan dengan kutipan percakapan sebagai berikut:

Teknisi/TU : PHT di SMP Muhammadiyah 7 Surakarta sudah menggunakan system online. Basisnya bisa android maupun pc. Jadi aplikasinya itu dioperasikan melalui handphone dan komputer. Semua yang mengatur pelaksanaannya adalah kurikulum. Seperti jadwal ujian, kegiatan mata pelajaran dan lain sebagainya. Untuk soal tes sudah guru masing-masing yang membuatnya. Untuk user name dan password sudah saya buatkan. Jadi anak tinggal login ke aplikasinya.

Berikut langkah-langkah terurut proses pelaksanaan PHT berbasis android di SMP Muhammadiyah 7 Surakarta.

Tabel 1. Proses Pelaksanaan PHT Berbasis Android

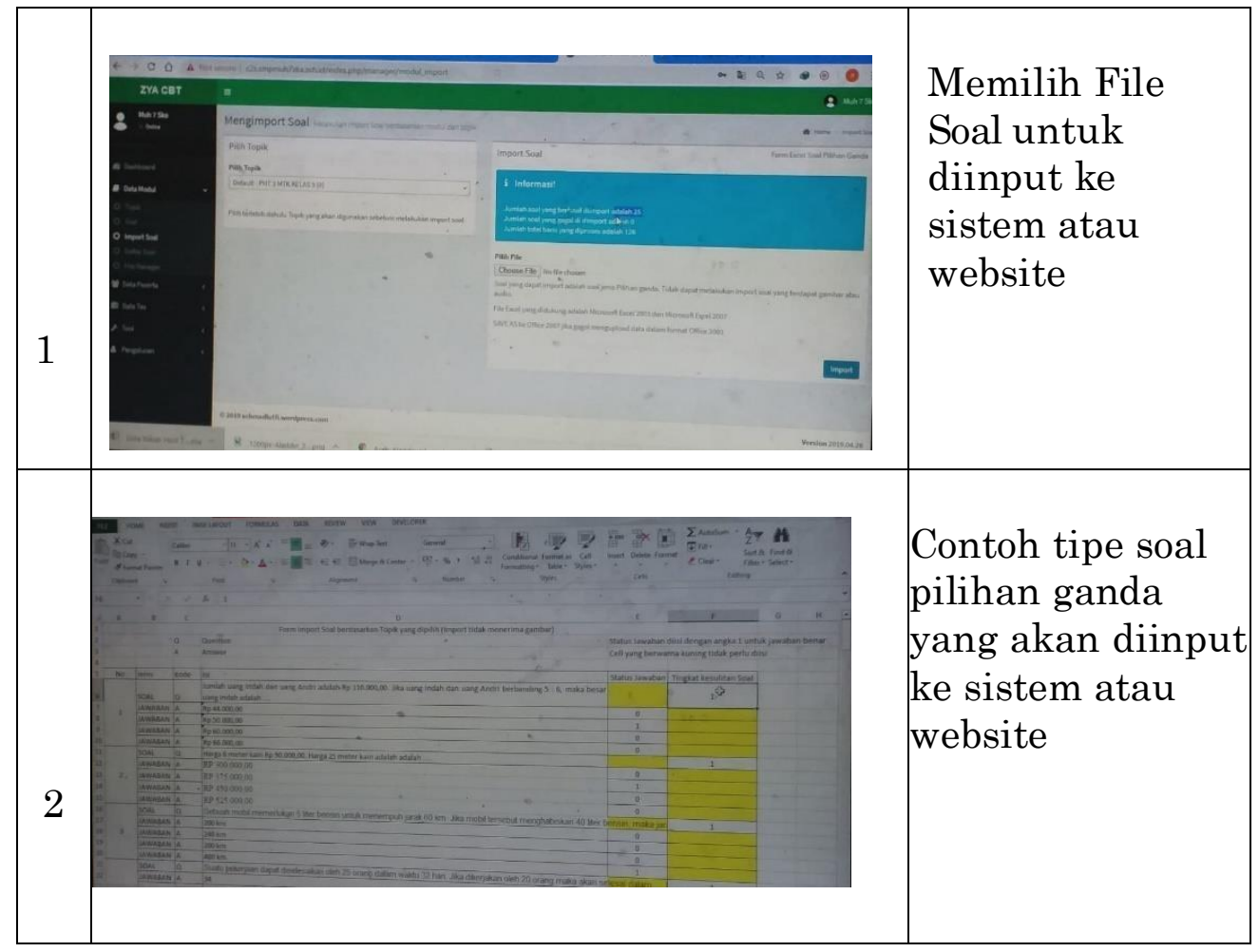




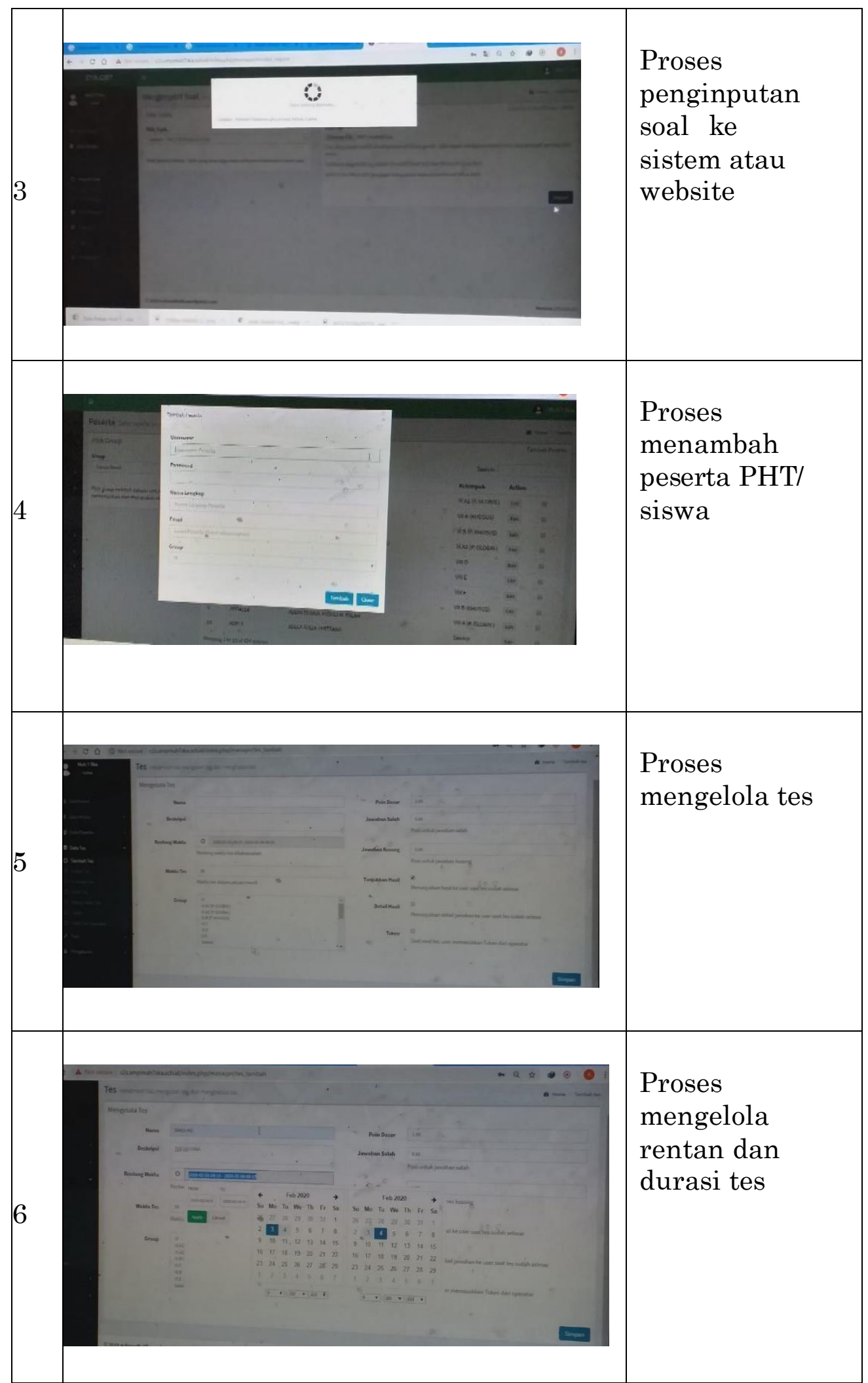




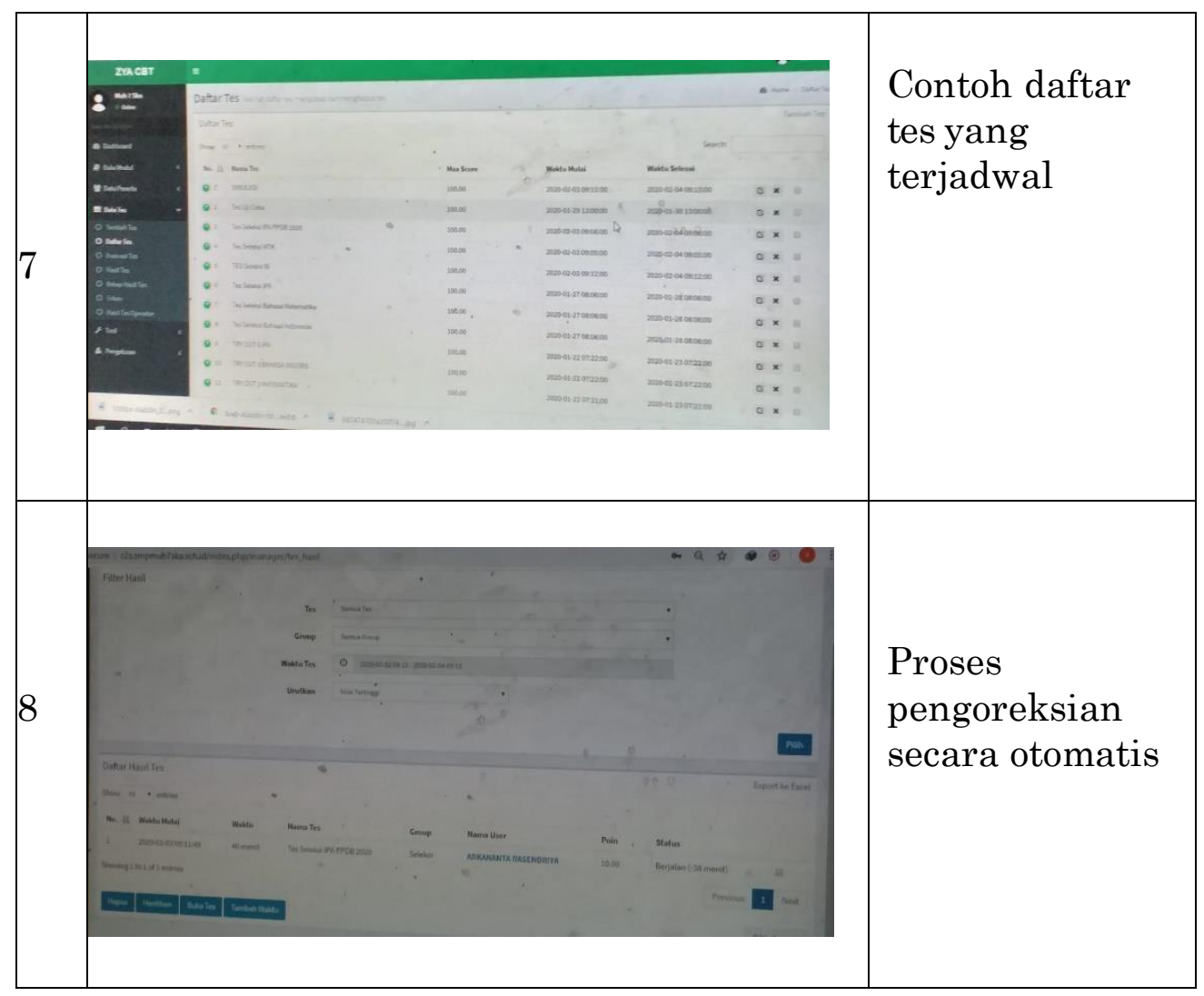

PHT dalam ulangan harian matematika dilaksanakan pada Jumat, 14 Februari 2020. Waktu pengerjaan adalah 60 menit dan soal yang diujikan berjumlah 25 pilihan ganda. Soal tersebut sebelumnya dibuat oleh guru, lalu diupload ke bagian teknisi. Sedangkan siswa mendapatkan username dan password untuk login ke dalam aplikasi. Setelah siswa mengerjakan, nilai sudah otomatis keluar disertai dengan kunci jawaban.
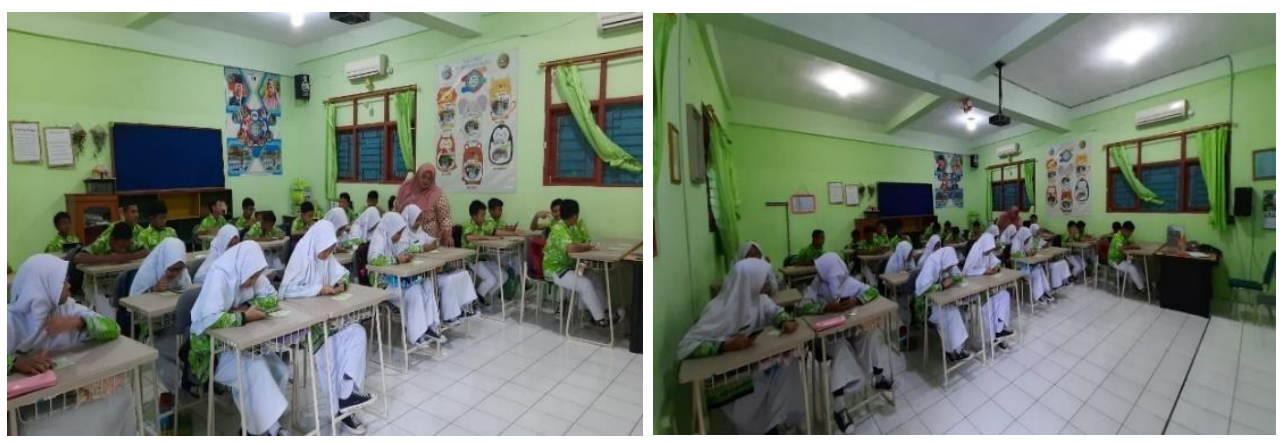

Gambar 4. Pelaksanaan PHT berbasis Android Kelas VIII A (Sumber: Dokumentasi Observasi)

\section{Perspektif Guru}

Perspektif guru di SMP Muhammadiyah 7 Surakarta yang diambil informasi dan data melalui wawancara. Menurut salah satu 
guru yang juga merupakan wakasek kurikulum sekolah mengatakan bahwa ia sangat mendukung salah satu program unggulan di sekolah ini yakni PHT (Penilaian Harian Terstruktur) berbasis android. Pelaksanaan PHT berbasis android di sekolah ini lebih efesien daripada ulangan harian secara manual. Dalam pelaksanaan PHT berbasis android ini memiliki beberapa kelebihan dan kelemahan atau ada sisi positif dan sisi negatifnya.

Untuk sisi positif atau kelebihan dari PHT berbasis android adalah kemudahan dan penghematan dari pihak guru seperti tidak perlu mencetak dan memfotokopi soal ujian sehingga membuat jumlah kertas menjadi lebih efesien. Selain itu, dalam proses pengoreksian tidak perlu memakan waktu banyak karena pengoreksisan dilakukan secara otomatis dan nilai pun langsung bisa keluar sehingga waktu juga dapat efesien.

Guru : Yang pertama Nilai langsung keluar dan tidak perlu menunggu lama waktu pengoreksian. Yang kedua tidak perlu mencetak soal dan memfotokopinya sehingga tidak perlu mengeluarkan banyak kertas. Yang ketiga bisa lebih irit biaya, meski kami tetap membayar programnya dengan harga yang tidak murah tapi, tidak apa-apa karena semuanya untuk kemudahan siswa dan guru.

Untuk sisi negative atau kekurangan dari PHT berbasis android terdapat pada kecurangan siswa. Banyak siswa yang membawa handphone lebih dari satu. Satu handphone dipakai untuk membuka kunci jawaban menggunakan password teman dan satunya lagi untuk mengerjakan soal. Selain itu, android hanya mampu melaksanakan ujian pilihan ganda karena android atau komputer hanya bisa mengerjakan soal dengan jawaban yang pasti.

Guru : Siswa lebih pandai (licik) dari guru. Banyak siswa membawa handphone lebih dari satu. Satu handphone dipakai untuk membuka kunci jawaban dengan cara log ini menggunakan password teman lalu di log out sehingga kunci jawaban keluar otomatis. Dan untuk handphone lainnya digunakan untuk mengerjakan soal. Android juga hanya mampu melaksanakan ujian pilihan ganda karena komputer hanya bisa jawaban yang pasti. Uraian memiliki jawaba yang tidak pasti sehingga ujian uraian belum bisa dilaksanakan secara android. Misalnya dalam uraian matematika hanya bisa jawaban pasti berupa angka (hasilnya) dan tanpa urutan cara mengerjakannya.

\section{Perspektif Siswa}

Untuk mengetahui minat siswa terhadap ulangan harian matematika menggunakan aplikasi Zambro dan website Zya Cbt, siswa diminta mengisi angket melalui Google Form yang berjumlah 5 pertanyaan dengan membubuhkan tanda ceklis pada rentangan jawaban yang dianggap tepat yaitu (1) ya; (2) tidak. 
1. Perspektif siswa tentang preferensi pengaruh PHT berbasis android.

Pertanyaan pertama yang diberikan di angket responden siswa adalah, "Apakah anda senang dalam menggunakan PHT berbasis android?" Berikut hasil pertanyaan pertama angket responden siswa:

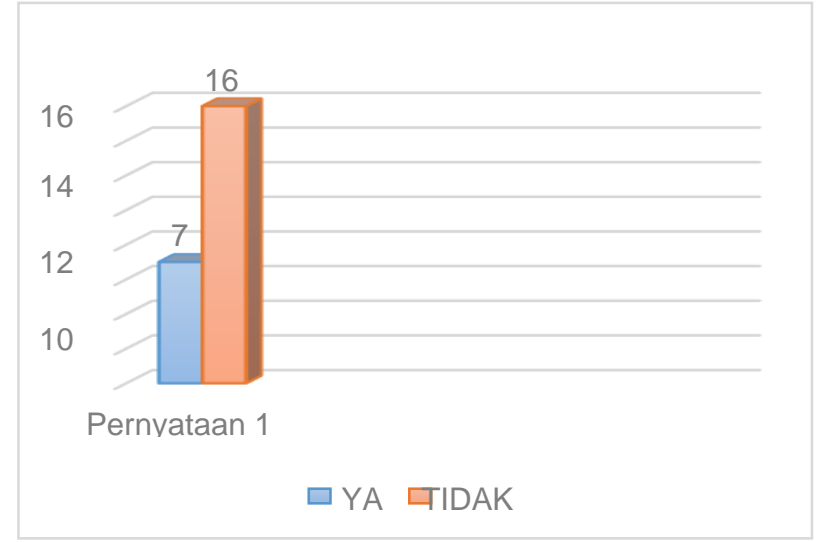

Gambar 5. Respon Siswa Terkait Preferensi Pengaruh PHT Berbasis Android

Berdasarkan data grafik di atas menjelaskan bahwa perspektif siswa tentang pengaruh PHT berbasis android terhadap perasaan senang masih rendah. Dari 23 siswa yang mengisi angket respon siswa sebagai hasil penelitian dari segi perspektif siswa, terdapat respon pilihan (ya) sebanyak 7 siswa dan respon (tidak) sebanyak 16 siswa. Untuk pilihan (ya) dalam pernyataan tersebut lebih sedikit daripada pilihan (tidak). Hal tersebut membuktikan bahwa pelaksanaan PHT berbasis android kurang mempengaruhi perasaan senang siswa.

2.Perspektif siswa tentang tingkat kesulitan PHT berbasis android.

Pertanyaan kedua yang diberikan di angket responden siswa adalah, "Apakah soal yang diujikan dapat dijawab dengan mudah?" Berikut hasil pertanyaan kedua angket responden siswa: 


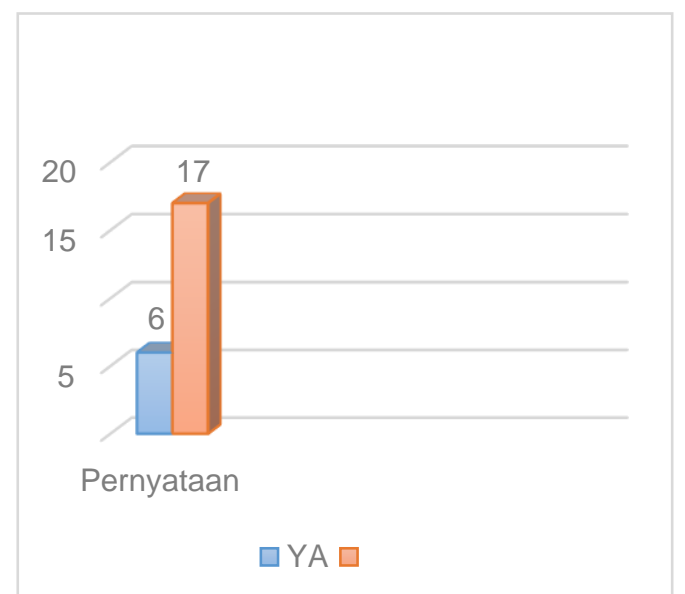

Gambar 6. Respon Siswa Terkait Tingkat Kesulitan Soal yang Diujikan

Berdasarkan data grafik di atas menjelaskan bahwa perspektif siswa tentang tingkat kesulitan PHT berbasis android masih rendah juga. Dari 23 siswa yang mengisi angket respon siswa sebagai hasil penelitian dari segi prespektif siswa, terdapat respon pilihan (ya) sebanyak 6 siswa dan respon (tidak) sebanyak 17 siswa. Untuk pilihan (ya) dalam pernyataan tersebut lebih sedikit daripada pilihan (tidak). Hal tersebut membuktikan bahwa pelaksanaan PHT berbasis android, sebagian besar siswa mengalami kesulitan dalam memahami soal ujian.

3.Perspektif siswa tentang pengaruh PHT berbasis android terhadap minat belajar.

Pertanyaan ketiga yang diberikan di angket responden siswa adalah, "Apakah menggunakan PHT berbasis android dapat meningkatkan minat belajar matematika siswa?" Berikut hasil pertanyaan ketiga angket responden siswa:

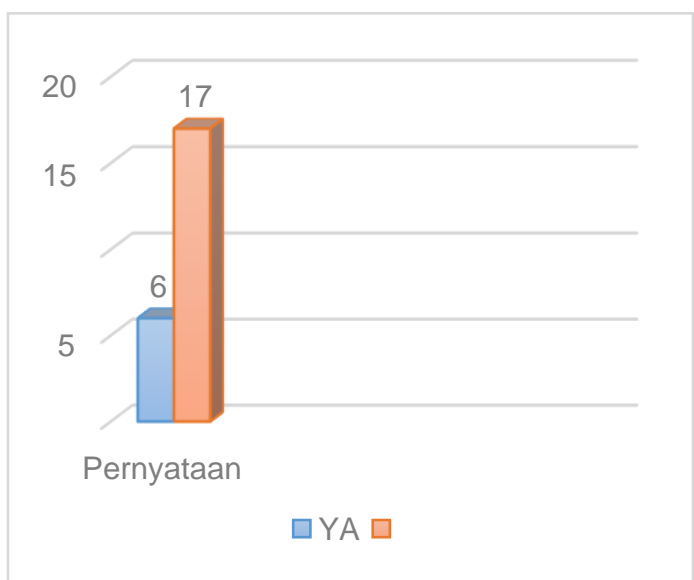

Gambar 7. Respon Siswa Terkait Pengaruh PHT Berbasis Android Terhadap Minat Belajar 
Berdasarkan data grafik di atas menjelaskan bahwa perspektif siswa tentang pengaruh PHT berbasis android terhadap minat belajar masih rendah. Dari 23 siswa yang mengisi angket respon siswa sebagai hasil penelitian dari segi prespektif siswa, terdapat respon pilihan (ya) sebanyak 6 siswa dan respon (tidak) sebanyak 16 siswa. Untuk pilihan (ya) dalam pernyataan tersebut lebih sedikit daripada pilihan (tidak). Hal tersebut membuktikan bahwa pelaksanaan PHT berbasis android kurang mempengaruhi minat belajar sebagian besar siswa.

4. Perspektif siswa tentang tingkat kejelasan tampilan gambar pada PHT berbasis android.

Pertanyaan keempat yang diberikan di angket responden siswa adalah, "Apakah tampilan gambar di PHT berbasis android terlihat jelas?" Berikut hasil pertanyaan keempat angket responden siswa:

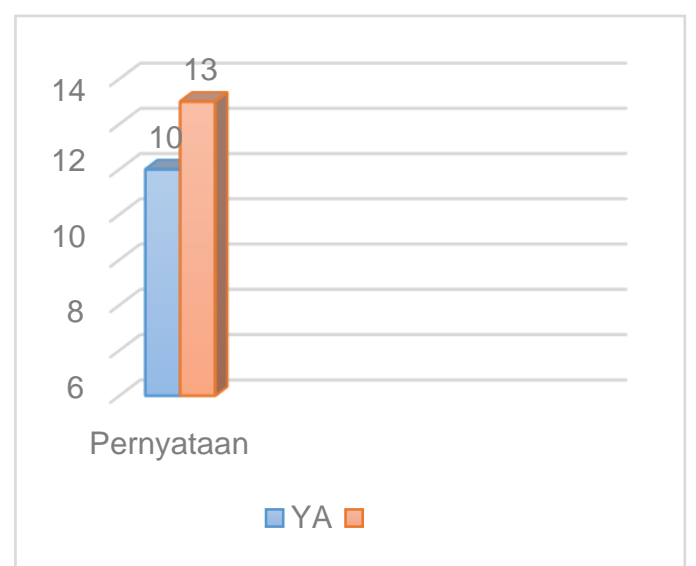

Gambar 8. Respon Siswa Terkait Tingkat Kejelasan Tampilan Gambar Pada PHT Berbasis Android

Berdasarkan data grafik di atas menjelaskan bahwa perspektif siswa tentang tingkat kejelasan tampilan gambar di PHT berbasis android masih rendah. Dari 23 siswa yang mengisi angket respon siswa sebagai hasil penelitian dari segi prespektif siswa, terdapat respon pilihan (ya) sebanyak 10 siswa dan respon (tidak) sebanyak 13 siswa. Untuk pilihan (ya) dalam pernyataan tersebut lebih sedikit daripada pilihan (tidak). Hal tersebut membuktikan bahwa pelaksanaan PHT berbasis android, sebagian besar siswa kurang dalam tingkat kejelasan tampilan gambar.

5.Perspektif siswa tentang ketertarikan tampilan awal PHT berbasis android.

Pertanyaan kelima yang diberikan di angket responden siswa adalah, "Apakah tampilan awal PHT berbasis android mudah?" Berikut hasil pertanyaan kelima angket responden siswa: 


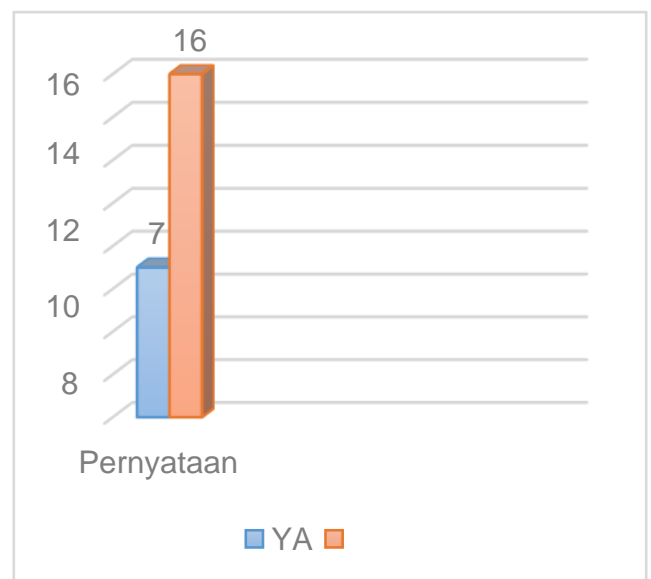

Gambar 9. Respon Siswa Terkait Keterkaitan Tampilan Awal PHT

Berbasis Android

Berdasarkan data grafik di atas menjelaskan bahwa perspektif siswa tentang ketertarikan tampilan awal PHT berbasis android masih rendah. Dari 23 siswa yang mengisi angket respon siswa sebagai hasil penelitian dari segi prespektif siswa, terdapat respon pilihan (ya) sebanyak 7 siswa dan respon (tidak) sebanyak 16 siswa. Untuk pilihan (ya) dalam pernyataan tersebut lebih sedikit daripada pilihan (tidak). Hal tersebut membuktikan bahwa pelaksanaan PHT berbasis android, sebagian besar siswa kurang tertarik pada tampilan awalnya.

Berdasarkan 5 data grafik di atas dapat disimpulkan bahwa hasil prespektif siswa yang diambil dari angket respon siswa masih terbilang sangat kurang melihat respon (tidak) lebih besar daripada respon (ya). Dengan adanya kesimpulan ini diharapkan sekolah mampu mengadakan evaluasi ulang tentang PHT berbasis android dengan melihat referensi artikel ilmiah ini. Diharapkan juga sekolah mampu meningkatkan inovasi baru dalam pengembangan salah satu program kerja sekolah ini.

Hasil penelitian ini apabila dibandingkan dengan penelitian terdahulu maka, terdapat perbedaan hasil penelitian dari segi perspektif. Penelitian ini terdapat perbedaan perspektif dari sisi guru dan siswa. Sedangkan pada penelitian terdahulu yang pertama terdapat kesamaan perspektif guru dan siswa dalam hal kelayakan dan ketertarikan aplikasi ujian (Rubhan Masykur dkk, 2017). Sama halnya dengan penelitian terdahulu kedua terdapat kesamaan perspektif guru dan siswa dalam hal kemudahan dalam proses ujian (Stephanie dkk, 2013). Selain itu, pada penelitian terdahulu ketiga juga terdapat kesamaan perspektif siswa dan guru dalam hal validasi aplikasi ujian (Hamsu dkk, 2017).

Penelitian ini memiliki keunggulan yang dapat dilihat dari segi metode ulangan harian berbasis android (mobile). PHT berbasis android di SMP Muhammdiyah 7 Surakarta berfungsi sebagai 
pelengkap atau pendukung kemudahan dalam melaksanakan ulangan harian. Selain itu berfungsi sebagai motivasi dan inovasi pengembangan android dalam melaksanakan program sekolah lainnya.

\section{SIMPULAN}

Dari hasil penelitian dapat disimpulkan bahwa penerapan PHT berbasis android di SMP Muhammadiyah 7 Surakarta berdasarkan perspektif guru dan teknisi sudah cukup baik. Hal ini disesuaikan dengan hasil observasi lingkungn sekolah dan wawancara. Namun, dari perspektif siswa penerapan PHT berbasis android masih rendah dan belum maksimal. Hal ini berdasarkan hasil angket responden siswa yang rata-rata memilih pilihan (tidak) sehingga menandakan bahwa penerapan PHT berbasis android kurang setuju apabila dijadikan sebagai program kerja sekolah.

\section{DAFTAR PUSTAKA}

Al-Karimah, A. Rusdi. Fachruddin, M. (2017). Efektivitas Media Pembelajaran Matematika Menggunakan Software Animasi Berbasis Multimedia Interaktif Model Tutorial Pada Materi Garis dan Sudut Untuk Siswa SMP/Mts kelas VII. Jurnal Penelitian Pembelajaran Matematika Sekolah. Vol. 1, No. 1, Agustus.

Haeriani, H. Gani, Hamsu. Mappalotteng, A. (2017). Efektivitas Media Pembelajaran Matematika Menggunakan Software Animasi Berbasis Multimedia Interaktif Model Tutorial Pada Materi Garis dan Sudut Untuk Siswa SMP/Mts Kelas VII. Universitas Negeri Makassar, Makassar.

Hasan, T. Putri, N. Salsabila, A. Wijayanto, B. (2019). Pelatihan Pembuatan dan Penggunaan Media Pembelajaran Matematika "SERU" pada Guru SD Negeri Kertonatan 2. PKM-M. Pendidikan Matematika. Universitas Muhammadiyah Surakarta.

Nawahoke, S. Jodhinata, A. (2013). Aplikasi Ulangan Harian Untuk Siswa SMA Berbasis Client Server. Jurnal GEMA AKTUALITA. Vol. 2, No. 2, Desember.

Prabowo, D. Supraptono, E. Safi'i, R. (2016). Efektivitas Aplikasi Berbasis Android Menggunakan Api Gesture Untuk Mengenal Aksara Korea. Jurnal Penelitian Tindakan Kelas. Vol. 17, No. 2, April. 
Ruangguru. (2016). Infografis: Penggunaan Teknologi dalam Pendidikan oleh Guru di Indonesia. URL: blog.ruangguru.com Diakses tanggal 6 Februari 2020. 